\title{
Pengaruh Inisiasi Menyusui Dini Terhadap Perubahan Suhu Badan Bayi Baru Lahir
}

\author{
Nancy Olii ${ }^{1}$, Tumarthony Hiola ${ }^{2}$ \\ ${ }^{1,2}$ Jurusan Kebidanan Poltekkes Kemenkes Gorontalo, \\ Email: @oliinancy7@gmail.com
}

\begin{abstract}
ABSTRAK
Latar Belakang : Angka Kematian Bayi (AKB) merupakan barometer pelayanan kesehatan bayi disuatu negara. Bila AKB masih tinggi berarti pelayanan kesehatan bayi belum baik. IMD merupakan salah satu program pemerintah dalam menurunkan AKB. IMD dimulai dengan adanya kontak kulit antara ibu dan bayi yang baru lahir kemudian dilanjutkan dengan pemberian ASI.

Tujuan : Tujuan penelitian ini untuk mengetahui pengaruh inisiasi menyusu dini terhadap perubahan suhu badan bayi baru lahir di wilayah kerja Puskesmas Dungaliyo Kabupaten Gorontalo.

Metode : Penelitian ini menggunakan jenis penelitian Quasy Eksperimen dengan pendekatan pretestposttest one group design. Populasi yang digunakan yaitu seluruh bayi baru lahir normal. Sampel yang digunakan berjumlah 30 bayi. Tehnik pengambilan sampel menggunakan purposive sampling. Variabel yang digunakan adalah variabel bebas yaitu Inisiasi Menyusu Dini dan variabel terikat yaitu perubahan suhu badan Bayi Baru Lahir.

Hasil : penelitian ini menunjukkan ada pengaruh inisiasi menyusu dini terhadap perubahan suhu badan bayi baru lahir setelah dilakukan Inisiasi Menyusu Dini.

Kesimpulan : inisiasi menyusu dini dapat mempengaruhi perubahan suhu badan bayi baru lahir.
\end{abstract}

\section{Kata kunci: Inisiasi Menyusu Dini, Suhu Badan, Bayi Baru Lahir}

\begin{abstract}
Background: Infant Mortality Rate (IMR) is a barometer of infant health services in a country. If the IMR is still high, it means that the baby's health service is not good. IMD is one of the government programs in reducing IMD. IMD begins with skin contact between the mother and newborn, then continues with breastfeeding.

Purpose: The purpose of this study was to determine the effect of early breastfeeding initiation on changes in body temperature of newborns in the working area of Dungaliyo Health Center, Gorontalo District.

Methods: This study used a quasi-experimental research type with a pretest-posttest one group design approach. The population used was all normal newborns. The sample used was 30 babies. The sampling technique used purposive sampling. The variables used were independent variables, namely Early Initiation of Breastfeeding, and the dependent variable namely changes in body temperature of newborns.

Results: This study showed that there was an effect of early initiation of breastfeeding on changes in body temperature of newborns after the Early Initiation of Breastfeeding.

Conclusion: early initiation of breastfeeding can affect changes in the body temperature of newborns.
\end{abstract}

\section{Keyword: Early Initiation of Breastfeeding, Body Temperature, Newborns}

\section{PENDAHULUAN}

Angka Kematian Bayi (AKB) merupakan barometer pelayanan kesehatan bayi disuatu negara. Bila AKB masih tinggi berarti pelayanan kesehatan bayi belum baik. Angka Kematian Bayi 
(AKB) di Indonesia tahun 2012 mencapai 32 per 1000 kelahiran hidup, tahun 2013 menurun menjadi 25 per 1000 kelahiran hidup sedangkan pada tahun 2015 AKB menunjukkan sebesar 22,23 per 1.000 kelahiran hidup ${ }^{(1)}$.

Angka kematian bayi di Provinsi Gorontalo mengalami capaian fluktuatif pada kurun waktu 4 tahun yakni pada tahun 2012 mencapai 18,7 per 1000 kelahiran hidup, mengalami penurunan signifikan ditahun 2013 yakni 13,3 per 1000 kelahiran hidup, angka ini kemudian mengalami kenaikan ditahun 2014 menjadi 13,9 per 1000 kelahiran hidup ${ }^{(2)}$ dan pada tahun 2015 menurun menjadi 11,5 per 1000 kelahiran hidup ${ }^{(\mathbf{1})}$.

IMD merupakan salah satu program pemerintah dalam menurunkan $\mathrm{AKB}$ terkait target pencapaian MDGs 2015. IMD dimulai dengan adanya kontak kulit antara ibu dan bayi yang baru lahir kemudian dilanjutkan dengan pemberian ASI ${ }^{(3)}$. Di Indonesia proses inisiasi menyusu dini meningkat menjadi 34,5 persen (2013) dari 29,3 persen (2010). Proses mulai menyusui terbanyak terjadi pada 1-6 jam setelah kelahiran $(35,2 \%)$ dan kurang dari 1 jam (inisiasi menyusui dini) sebesar $34,5 \%$. Sedangkan proses mulai menyusui terendah terjadi pada 7-23 jam setelah kelahiran yaitu sebesar $3,7 \%$ (4)

Bayi melakukan Inisiasi Menyusu Dini mempunyai dampak yang positif. Bagi bayi, menyusui mempunyai peran penting, kehangatan saat menyusu menurunkan risiko kematian bayi karena hipotermia (kedinginan), menunjang pertumbuhan, kesehatan, dan kelangsungan hidup bayi karena ASI kaya dengan zat gizi dan antibody $(4)$.

Adapun dampak yang dapat terjadi jika tidak dilakukan IMD pada bayi baru lahir yaitu AKB oleh hipotermia akan meningkat, karena Bayi baru lahir kehilangan panas empat kali lebih besar dari pada orang dewasa, sehingga mengakibatkan terjadinya penurunan suhu. Pada 30 menit pertama bayi dapat mengalami penurunan suhu $3-4^{0} \mathrm{C}$. Pada ruangan dengan suhu $20-25^{\circ} \mathrm{C}$ suhu kulit bayi turun sekitar $0,30 \mathrm{C}$ per menit. Penurunan suhu diakibatkan oleh kehilangan panas secara konduksi, konveksi, evaporasi dan radiasi ${ }^{(5)}$.

Kemampuan bayi yang belum sempurna dalam memproduksi panas maka bayi sangat rentan untuk mengalami hipotermia. Suhu bayi yang rendah mengakibatkan proses metabolik dan fisiologi melambat. Kecepatan pernafasan dan denyut jantung sangat melambat, tekanan darah rendah dan kesadaran menghilang. Bila keadaan ini terus berlanjut dan tidak mendapatkan penanganan maka dapat menimbulkan kematian pada bayi baru lahir ${ }^{(5)}$

Menurut hasil penelitian Ernawaty, Nanik tahun 2019 menunjukkan bahwa suhu tubuh bayi baru lahir setelah pelaksanaan IMD berada dalam keadaan stabil dikarenakan ibu dan bayi tampak lebih tenang dan bahagia. Kulit tubuh ibu mampu mengontrol kehangatan dadanya sesuai kebutuhan bayinya, hal ni akan membuat bayi akan berada pafda suhu tubuh yang optimal sehingga bayi merasa lebih tenang dan nyaman, tidak hanya untuk memberikan keuntungan mencegah hipotermi saja, keadaan emisional ibu dan bayi dengan kata lain ikatan kasih sayang (bonding) antara ibu dan bayi terjalin dengan baik, hal ini akan memberikan dampak yang besar untuk perkembangan bayi, karena ikatan kasih sayang telah terjalin dengan baik.

Kematian bayi di Kecamatan Dungaliyo pada tahun 2013 yaitu 11 jiwa, tahun 2014 menurun menjadi 7 jiwa, 2015 menurun menjadi 2 sedangkan pada tahun 2016 kematian neonatal diwilayah kerja Puskesmas Dungaliyo meningkat lagi, dalam kurun waktu satu tahun lahir 252 bayi, yang meninggal 7 bayi jika dipersenkan AKB di Wilayah Kerja Puskesmas Dungaliyo 2,7 \%. Penyebab kematian bayi 100\% disebabkan karena berat badan lahir rendah dengan komplikasi hipotermia.

Berdasarkan uraian di atas maka penulis tertarik untuk melakukan penelitian mengenai "Pengaruh Inisiasi Menyusu Dini terhadap perubahan suhu badan bayi baru lahir di wilayah 
kerja Puskesmas Dungaliyo".

\section{METODE}

Penelitian ini menggunakan rancangan penelitian Quasi Eksperimen, dengan pendekatan pretest-posttest one group design, yang dilaksanakan pada bulan April - Juni 2017 di wilayah kerja Puskesmas Dungaliyo Kabupaten Gorontalo. Pada rancangan ini awal pengamatan dilakukan pretest yaitu pengukuran suhu badan bayi menggunakan termometer digital pada daerah aksila bayi yang sebelumnya mengukur suhu badan ibu terlebih dahulu. Setelah itu intervensi dengan tengkurapkan bayi di dada ibu untuk melakukan kontak kulit ke kulit atau melakukan inisiasi menyusu dini selama 1 jam. Posisi ibu berbaring dan bayi diatas dada ibu dengan posisi seperti katak dengan mata sejajar putting susu ibu. Kemudian dilakukan post test dengan mengukur kembali suhu badan bayi baru lahir.

Populasi dalam penelitian ini adalah bayi baru lahir dengan persalinan normal di wilayah kerja Puskesmas Dungaliyo Kabupaten Gorontalo dengan sampel yang memenuhi kriteria sebanyak 30 bayi, dengan teknik sampling Purposive sampling. Variabel bebas dalam penelitian ini adalah Inisiasi Menyusu Dini dan variabel terikat adalah Perubahan Suhu Badan pada Bayi Baru Lahir. Responden mempunyai karakteristik yang terdiri dari waktu inisiasi menyusu dini, suhu badan sebelum dan sesudah inisiasi menyusu dini.

\section{HASIL}

Tabel 1 Distribusi frekuensi jenis kelamin, jenis persalinan, dan penolong persalinan

\begin{tabular}{lcc}
\hline & Jumlah & $\%$ \\
\hline Jenis Kelamin & & \\
Laki-laki & 13 & 43.3 \\
Perempuan & 17 & 56.7 \\
Jenis Persalinan & & \\
Normal & 30 & 100 \\
SC & 0 & 0 \\
Penolong persalinan & & \\
Bidan & 30 & 100 \\
Dokter & 0 & 0 \\
\hline
\end{tabular}

Berdasarkan tabel 1 bahwa bayi baru lahir dengan jenis kelamin perempuan sebanyak 17 responden $(56.7 \%)$ dan laki-laki sebanyak 13 responden (43.3\%). Seluruh responden dilahirkan secara normal ditolong oleh bidan

Tabel 2. Suhu bdan sebelum dan sesuah IMD

\begin{tabular}{ccccc}
\hline Suhu Badan & \multicolumn{2}{c}{$\begin{array}{c}\text { Suhu badan responden } \\
\text { sebelum IMD }\end{array}$} & \multicolumn{2}{c}{$\begin{array}{c}\text { Suhu badan responden } \\
\text { sesudah IMD }\end{array}$} \\
\cline { 2 - 5 } & Jumlah & $\%$ & Jumlah & $\%$ \\
\hline $35-35,9$ & 20 & 66,7 & 0 & 0 \\
$36-36,9$ & 10 & 33,3 & 25 & 83,3 \\
$37-37,9$ & 0 & 0 & 5 & 16,7 \\
\hline
\end{tabular}

tabel 2 Menunjukkan perubahan suhu badan

1. Analisis Bivariat

sebelum dan sesudah dilakukan IMD.

Volume 7 Nomor 2. Januari - Juni 2020 
Analisis bivariat digunakan untuk mengetahui pengaruh antara inisiasi menyusu dini terhadap perubahan suhu badan bayi baru lahir di Wilayah Kerja Puskesmas Dungaliyo Kabupaten Gorontalo.Setelah data terkumpul selanjutnya dilakukan analisis untuk menguji normalitas data dengan menggunakan bantuan SPSS 16. Didapatkan bahwa Kolmogorovsmirnov yaitu 0.115 dan 0.057 yang artinya bahwa data telah terdistribusi normal.

Tabel 3. Pengaruh inisiasi Menyusu Dini Terhadap Perubahan Suhu Badan Bayi Baru Lahir

\begin{tabular}{cccc}
\hline \multirow{2}{*}{$\begin{array}{c}\text { Inisiasi Menyusu } \\
\text { Dini }\end{array}$} & Suhu Badan & Suhu Badan & \\
& Sebelum IMD & Sesedah IMD & \multirow{2}{*}{ Sig. (2 Tailed) } \\
\cline { 2 - 3 } & Mean \pm SD & Mean \pm SD & \\
\hline $\mathrm{N}=30$ bayi & $36.08 \pm 0.284$ & $36.70 \pm 0.255$ & 0.001 \\
\hline
\end{tabular}

Berdasarkan tabel 3, menunjukan hasil bahwa bayi yang dilakukan inisiasi menyusu dini sebelum dan setelah seluruh bayi baru lahir mengalami perubahan suhu badan yang signifikan dengan nilai $\mathrm{p}=0.001<\alpha=0.005$ dengan demikian $\mathrm{H}_{0}$ ditolak artinya ada pengaruh Inisiasi Menyusu Dini terhadap perubahan suhu badan bayi baru lahir di wilayah kerja Puskesmas Dungaliyo Kabupaten Gorontalo.

\section{PEMBAHASAN}

Penelitian ini sejalan dengan penelitian yang dilakukan oleh Hutagaol dkk tahun 2014 di RS Tk. III Dr. Reksodiwiryo Padang. Pada penelitiannya didapatkan hasil bahwa setelah dilakukan IMD selama satu jam maka rerata suhu aksila pada kelompok IMD lebih tinggi dari pada kelompok non IMD. Rerata suhu aksila kelompok IMD sebesar $37,1 \pm 0,2^{\circ} \mathrm{C}$ dan rerata suhu aksila pada kelompok non IMD sebesar $36,8 \pm 0,4^{\circ} \mathrm{C}$. Hal ini menunjukkan bahwa IMD yang dilakukan pada bayi baru lahir mempunyai pengaruh yang sangat baik untuk dapat mempertahankan suhu pada bayi baru lahir.
Hasil penelitian Utami, (2013) di RB Paten menunjukkan suhu tubuh rata-rata bayi yang tidak dilakukan inisiasi menyusu dini adalah $36,26^{\circ} \mathrm{C}$ sedangkan pada bayi baru lahir yang dilakukan inisiasi menyusu dini suhu tubuh rata-rata adalah $36,94^{\circ} \mathrm{C}$ hal tersebut menggambarkan bahwa adanya perbedaan suhu pada bayi baru lahir pada bayi yang tidak dilakukan inisiasi menyusu dini dengan suhu bayi baru lahir yang dilakukan inisiasi menyusu dini. Hasil uji t-independent menunjukkan perbedaan rata-rata suhu tubuh bayi baru lahir kelompok kontrol dan kelompok intervensi adalah $0,68^{\circ} \mathrm{C}$.

Penelitian Wardani, dkk tahun 2017, menunjukkan bahwa setelah dilakukan IMD terhadap bayi baru lahir terjadi perubahan suhu tubuh yaitu yang pada awalnya suhu tubuh bayi hampir seluruhnya bersuhu tubuh rendah mengalami kenaikan $1^{0}-2^{\circ} \mathrm{C}$ hingga suhu tubuh dalam nilai normotermi.

Menurut penelitian Chaidir Reny (2016), setelah dilakukan penelitian didapatkan hasil bahwa rata-rata suhu tubuh bayi baru lahir sebelum pelaksanaan IMD sebesar $36,52^{\circ} \mathrm{C}$ dengan suhu tubuh bayi baru lahir setelah pelaksanaan IMD 
JIDAN

Jurnal Ilmiah Bidan

sebesar $37,31^{\circ} \mathrm{C}$. Hal ini menunjukkan adanya peningkatan suhu sebesar $0,79^{\circ} \mathrm{C}$ yang menandakan adanya pengaruh IMD terhadap suhu tubuh bayi baru lahir

Berdasarkan penelitian terdahulu peneliti mengasumsikan bahwa bayi baru lahir belum dapat mengatur suhu tubuhnya, sehingga akan cenderung mengalami stres fisik akibat adanya perubahan suhu di luar uterus. Inisiasi Menyusu Dini merupakan proses pembiaran bayi menyusu sendiri setelah kelahiran. Keuntungan inisiasi menyusu dini yaitu dapat mempertahankan suhu badan bayi agar tetap hangat dan dapat merangsang kontraksi uterus sehingga mengurangi resiko sesudah melahirkan.

Kehilangan panas terjadi melalui Radiasi yaitu panas yang hilang dari obyek yang hangat (bayi) ke obyek yang dingin, Konduksi yaitu hilangnya panas langsung dari obyek yang panas ke obyek yang dingin, Konveksi yaitu hilangnya panas dari bayi ke udara sekelilingnya dan Evaporasi yaitu hilangnya panas akibat penguapan air dari kulit tubuh bayi misalnya cairan amnion pada bayi baru lahir.

Cara bayi melakukan IMD ini juga dapat dinamakan merangkak mencari payudara atau the breast crawl, kontak antara kulit ibu dan kulit bayi segera dalam satu jam kelahiran pertama sangat penting karena dada ibu menghangatkan bayi dengan tepat selama bayi merangkak mencari payudara ${ }^{(\mathbf{1 0})}$.

Menurut penelitian Zulala (2017) dan Hilmy, Pertiwy (2015) bahwa IMD menyebabkan stimulasi vagal lewat rangsangan sentuhan dan bau serta menginduksi pelepasan hormon oxytosin pada ibu sehingga menyebabkan suhu payudara
ISSN : 23391731 (print), 2581-1029 (online)

ibu meningkat yang dapat menjaga suhu bayi saat dilakukan IMD. Kulit ibu merupakan termoregulator yang tepat bagi bayi, suhu kulit dada ibu akan menyesuaikan dengan suhu tubuh bayi, jika bayi kedinginan, suhu kulit ibu naik dua derajat secara otomatis untuk menghangatkan bayi sehingga menurunkan risiko hipotermi, ketika suhu bayi meningkat maka suhu kulit ibu otomatis turun satu derajat untuk menstabilkan suhu bayi.

Isapan bayi selama pelaksanaan IMD mampu menstimulasi sekresi hormon prolaktin yang berperan dalam produksi ASI di tingkat alveoli. Isapan-isapan selanjutnya merangsang refleks prolaktin pada putting susu lebih sering sehingga produksi ASI semakin banyak. Kontak kulit ibu dengan kulit bayi dapat meningkatkan keterampilan bayi untuk menyusu lebih cepat dan efektif serta mampu meningkatkan hubungan psikologis antara ibu dengan anak ${ }^{(13)}$.

Hal ini juga sangat menguntungkan bagi tenaga kesehatan yang menolong. IMD dapat mencegah perdarahan dan saat tenaga kesehatan melakukan penanganan lainnya, seperti pengeluaran plasenta dan penjahitan laserasi jika ada, ibu berada dalam keadaan tenang sehingga tenaga kesehatan dapat bekerja dengan tenang dan nyaman (14)

Saat proses Inisiasi Menyusu Dini (IMD) untuk mencegah bayi kedinginan dapat diberikan selimut yang akan menyelimuti bagian punggung bayi dan ibunya serta kepala bayi diberi topi. Dari hasil penelitian didapatkan adanya pengaruh penggunaan Selimut Inisiasi Menyusu Dini (SIMDi) terhadap suhu tubuh bayi setelah pelaksanaan Inisiasi Menyusu Dini (IMD), dengan rata-rata suhu $36.82^{\circ} \mathrm{C}$, sedangkan suhu tubuh bayi yang 
menggunakan selimut kontemporer hanya meningkat rata-rata $36,36^{0} \mathrm{C}$ (15).

Upaya untuk mengurangi resiko hipotermi pada bayi baru lahir yaitu dengan melakukan inisiasi menyusu dini. Inisiasi menyusu dini merupakan salah satu upaya pemerintah untuk menurunkan angka kematian bayi dengan mengeluarkan Peraturan Menteri kesehatan 39 Tahun 2016 pasal 2 salah satunya yaitu menurunkan angka kematian ibu dan bayi. Dalam upaya menurunkan angka kematian bayi dan mensosialisasikan pentingnya manfaat dari inisiasi menyusu dini, perlu diupayakan program yang dapat meningkatkan IMD. Agar program tersebut tepat sasaran dan sesuai dengan target yang ingin dicapai maka harus diketahui terlebih dahulu faktor yang berhubungan dengan pelaksanaan IMD.

\section{KESIMPULAN}

Hasil kesimpulan dari penelitian ini adalah bayi baru lahir di wilayah kerja Puskesmas Dungaliyo sebelum dilakukan Inisiasi menyusu dini memiliki suhu badan dibawah $36.2^{\circ} \mathrm{C}$ sebanyak 23 bayi dan bayi baru lahir di wilayah kerja Puskesmas Dungaliyo sesudah dilakukan Inisiasi menyusu dini mengalami peningkatan suhu badan rata-rata $0,6^{\circ} \mathrm{C}$. Penelitian ini juga menunjukkan bahwa ada pengaruh antara inisiasi menyusu dini terhadap perubahan suhu badan bayi baru lahir di wilayah kerja Puskesmas Dungaliyo Kabupaten Gorontalo.

\section{SARAN}

Disarankan agar bidan dapat memberikan informasi kepada masyarakat tentang pentingnya inisiasi menyusu dini dan memprioritaskan pertolongan persalinan dengan melakukan inisiasi menyusu dini pada setiap ibu bersalin untuk menurunkan angka kematian bayi.

\section{DAFTAR PUSTAKA}

1. Kementerian Kesehatan Indonesia, 2015, Profil Kesehatan Indonesia, https://www.google.co.id, diakses pada tanggal 13 januari 2017.

2. Kementerian Kesehatan Indonesia, 2014, Profil Kesehatan Indonesia, https://www.google.co.id, diakses pada tanggal 13 januari 2017.

3. Mohamad dkk, 2015, Faktor-faktor yang Berhubungan dengan Pelaksanaan Inisiasi Menyusu Dini oleh Bidan di Rumah Sakit Prof. Dr. Aloei Saboe Kota Gorontalo, Jurnal JIKMU, Vol. 5, No. 2a, Gorontalo.

4. Kementerian Kesehatan Indonesia, 2013, Riskesdas, https://www.google.co.id, diakses pada tanggal 13 januari 2017.

5. Hutagaol, dkk, 2014, Pengaruh Inisiasi Menyusu Dini (IMD) Terhadap Suhu dan Kehilangan Panas pada Bayi Baru Lahir, Jurnal Kesehatan, Padang.

6. Ernawati, Nanik, 2019, Hubungan Inisiasi Menyusu Dini dengan Kestabilan Suhu Tubuh pada Bayi Baru Lahir di RS Muhamadiyah Gresik Kabupaten Gresik, Jurnal Kebidanan, Vol. 05, No. 02.

7. Utami, dkk, 2013, Pengaruh Inisiasi Menyusu Dini (IMD) terhadap Suhu Tubuh Bayi Baru Lahir di Rumah Bersalin Paten Rejowinangun Utara Magelang Selatan, Jurnal Ilmiah Ilmu-Ilmu Kesehatan, Vol. XV, No. 3.

8. Wardani, dkk, 2019, Pengaruh Inisiasi Menyusu Dini (IMD) Terhadap Perubahan Suhu, Vol. 1, No. 1.

9. Chaidir Reny, 2016, Pengaruh Inisiasi Menyusu Dini terhadap Suhu Tubuh Bayi Baru Lahir di BPM Padang Panjang, Vol. 11, No. 1.

10. Yuwansyah, Desi, 2019, Gambaran Pelaksanaan Inisiasi Menyusu Dini (IMD) dan Perubahan Suhu .Pengaruh Inisiasi Menyusui Dini.... 
pada Bayi Baru Lahir di BPM Bidan Dewi Padahanten, Vol. 04, No. 10.

11. Zulala, dkk. Skripsi Pengaruh Inisiasi Menyusu Dini Terhadap Hipotermi Pada Bayi Baru Lahir.

12. Wildan, Pertiwi, 2015, Pengaruh Inisiasi Menyusu Dini terhadap Kejadian Hipotermia pada Bayi Baru Lahir di Puskesmas Sumbersari Kabupaten Jember, Vol. 11, No. 01.

13. Budiani, dkk, 2014, Manfaat Inisiasi Menyusu Dini dalam Menjaga Kestabilan Suhu Tubuh Bayi Baru Lahir dan Frekuensi Menyusui dalam 24 Jam Pertama Masa Nifas, Vol. 11, No. 02.

14. Izzati, Rini, 2015, Pengaruh Inisiasi Menyusu Dini (Imd) Terhadap Suhu Tubuh Bayi Baru, Vol.2, No.2.

15. Sudarmi, dkk, 2019, Pengaruh Penggunaan Selimut Inisiasi Menyusu Dini (SIMDI) terhadap Suhu Tubuh Bayi Saat Inisiasi Menyusu Dini (IMD), Jurnal Kesehatan, Vol. 10, No. 01. 